\title{
Corrosion of Low-Alloy Irons and Steels in Soils
}

\section{Irving A. Denison and Melvin Romanoff}

\begin{abstract}
The results of measurements of the corrosion of 10 low-alloy irons and steels exposed to 14 soils for periods up to 13 years are given. The magnitude and progress of corrosion as determined by weight-loss and pit-depth measurements are correlated with the composition of the materials and the nature of the environmental conditions to which the test specimens were exposed.
\end{abstract}

\section{Introduction}

In 1932 the National Bureau of Standards in cooperation with a number of manufacturers and consumers of pipe materials initiated an extensive investigation of the corrosion of certain materials used in underground construction. Examination of the test specimens removed during the early periods of exposure indicated that certain alloy steels had improved corrosion resistance over ordinary irons and steels. Consequently, specimens representing a greater variety of alloy irons and steels were installed at the sites at intervals during the course of the exposure tests. The condition of the specimens removed from the various sites after successively longer periods of exposure has been described in a series of progress reports, and in 1950 a final report on the specimens buried in 1932 was published [1]. ${ }^{1}$ The present report contains the results of measurements of weight loss and pitting on samples of 10 varieties of irons and steels that were exposed in 1937 and removed from the test sites after five periods of exposure, ranging from 2- to 13-yr duration. The properties of the soils at the test sites, the installation of the specimens at the sites, and the methods used in cleaning the specimens removed prior to 1946 are described in earlier papers $[1,2]$. Specimens subsequently removed were cleaned by immersion in fused sodium hydride [3].

\section{Description of the Materials}

The specimens were in the form of plates 12 in. long and 25 in. wide, ranging in thickness from
0.175 to 0.265 in. The compositions of the materials are given in table 1.

\section{Results of the Exposure Tests}

The corrosion of the different materials in typical soils is illustrated in figures 1 and 2. Each of the four environmental groups based on aeration is represented as follows: good aeration, soil 55; fair aeration, soil 66 ; poor aeration, soil 61 ; and very poor aeration, soil 56 .

The extent of corrosion damage was determined from the loss in weight of the specimens as a result of the exposure, and from the depths of the deepest pits. The results of these measurements for the different periods of exposure are given in tables 2 and 3 . Unless indicated otherwise, these values are the averages of measurements on two specimens. The exposure periods did not differ from the average values given in the tables by more than 5 percent.

A number of the specimens exposed for the longer periods in the more corrosive soils were perforated by pitting. Because the depths of the pits producing these perforations would obviously have been greater after successively longer periods of exposure if thicker specimens had been used, some adjustment of the values for pitting of the perforated specimens was desirable. An approximate adjustment was made by multiplying the average penetration of the perforated specimens by the pitting factor, defined as the ratio of the maximum to the average penetration. Denison and Hobbs [4] showed that the pitting factor of plain irons and steels decreased with time during the early periods of exposure underground but became approximately constant after exposures for 6 to $8 \mathrm{yr}$. The value of the pitting factor was con-

TABLE 1. Composition of the materials

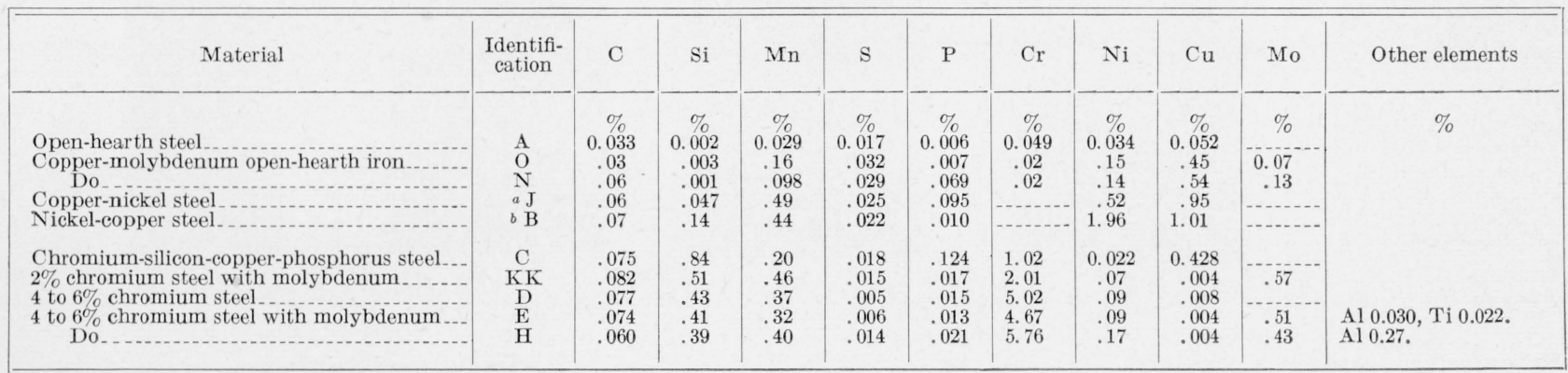

a Some mill scale on the specimens at time of burial.

$b$ Specimens completely covered with a hard, black mill scale at the time of burial.

1 Figures in brackets indicate the literature references at the end of this paper. 


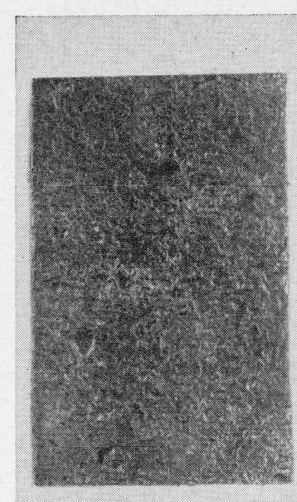

\section{SOIL 55}
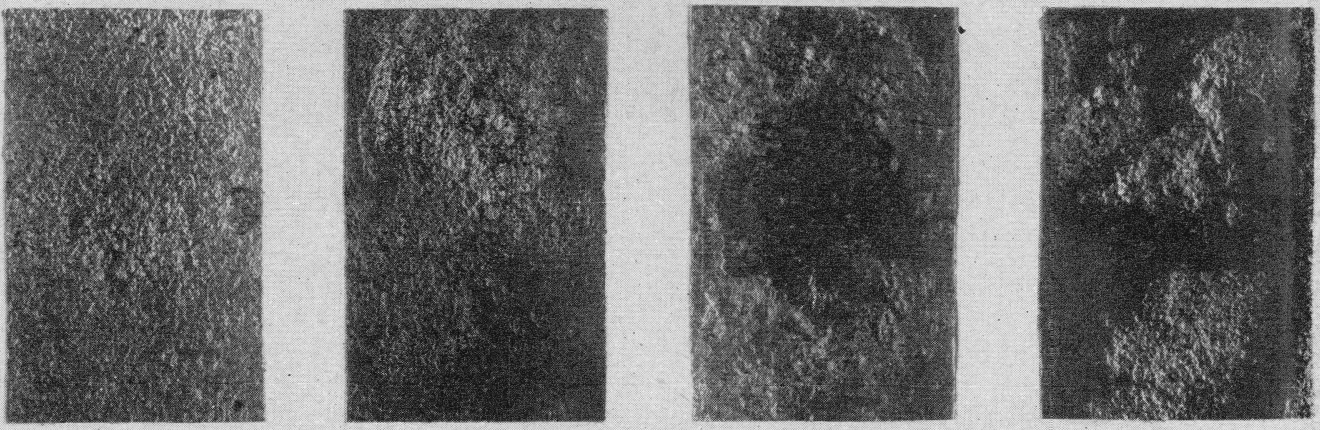

SOIL 66
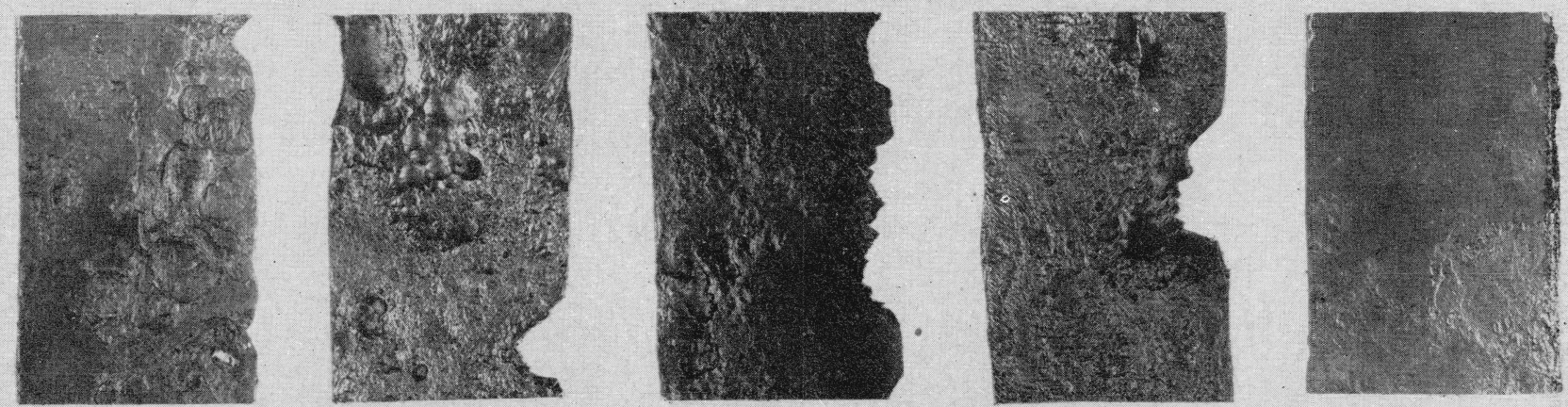

\section{SOIL $6 I$}
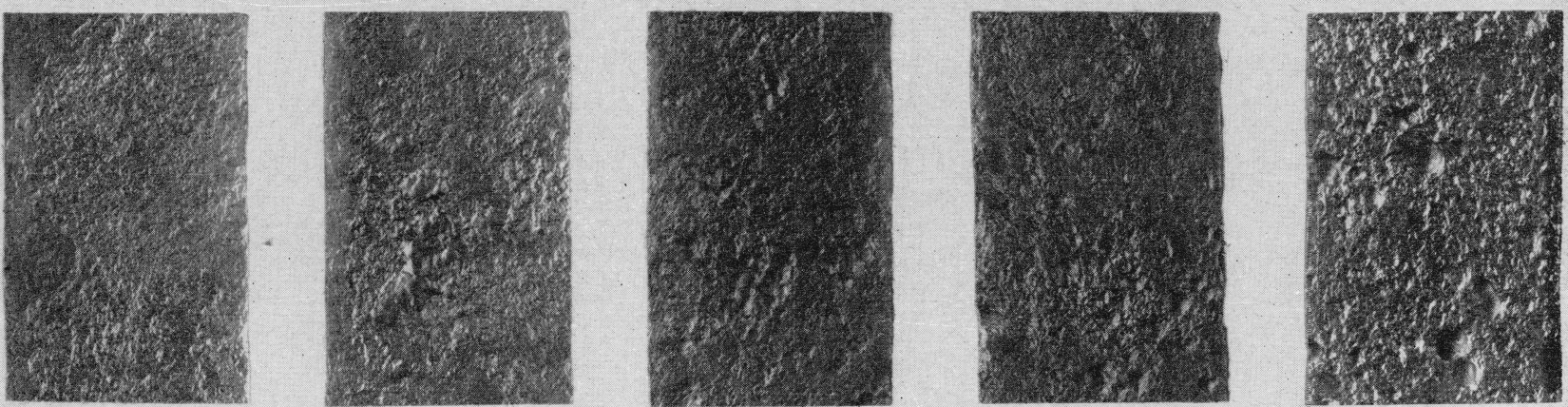

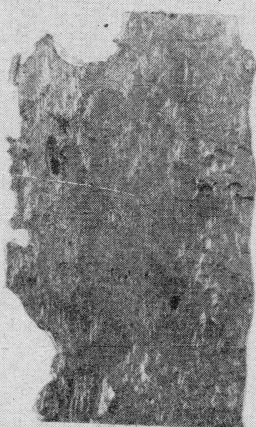

A

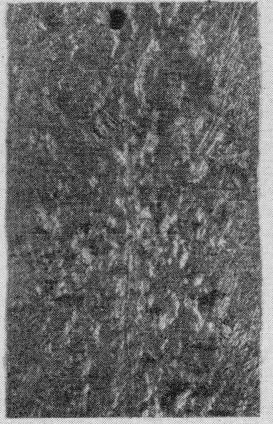

0

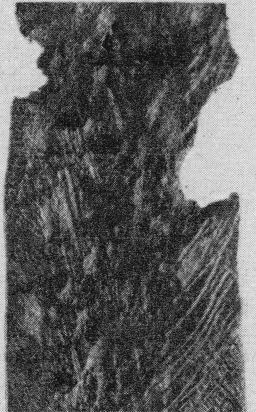

J

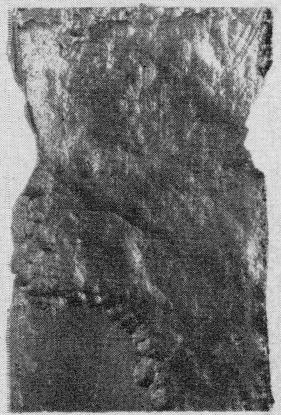

B

Figure 1. Corrosion of plain steel, copper-molybdenum open-hearth irons and nickel-copper steels in several soil environments A, open-hearth steel; O, open-hearth iron, $0.45 \mathrm{Cu}, 0.07 \mathrm{Mo} ; \mathrm{N}$, open-hearth iron, $0.54 \mathrm{Cu}, 0.13 \mathrm{Mo}$; J, steel, $0.95 \mathrm{Cu}, 0.52 \mathrm{Ni}$; B, steel, $1.95 \mathrm{Ni}, 1.01 \mathrm{Cu}$. Soil 55 . well-oxidized acid silt loam deficient in soluble salts; soil 66 , fairly well aerated alkaline loam containing a high concentration of soluble material; soil 61 , poorly aerated clay containing a moderate amount of soluble material; soil 56 , very poorly aerated heavy clay containing a high concentration of soluble salts. 


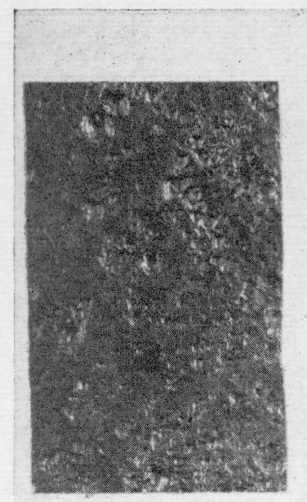

SOIL 55
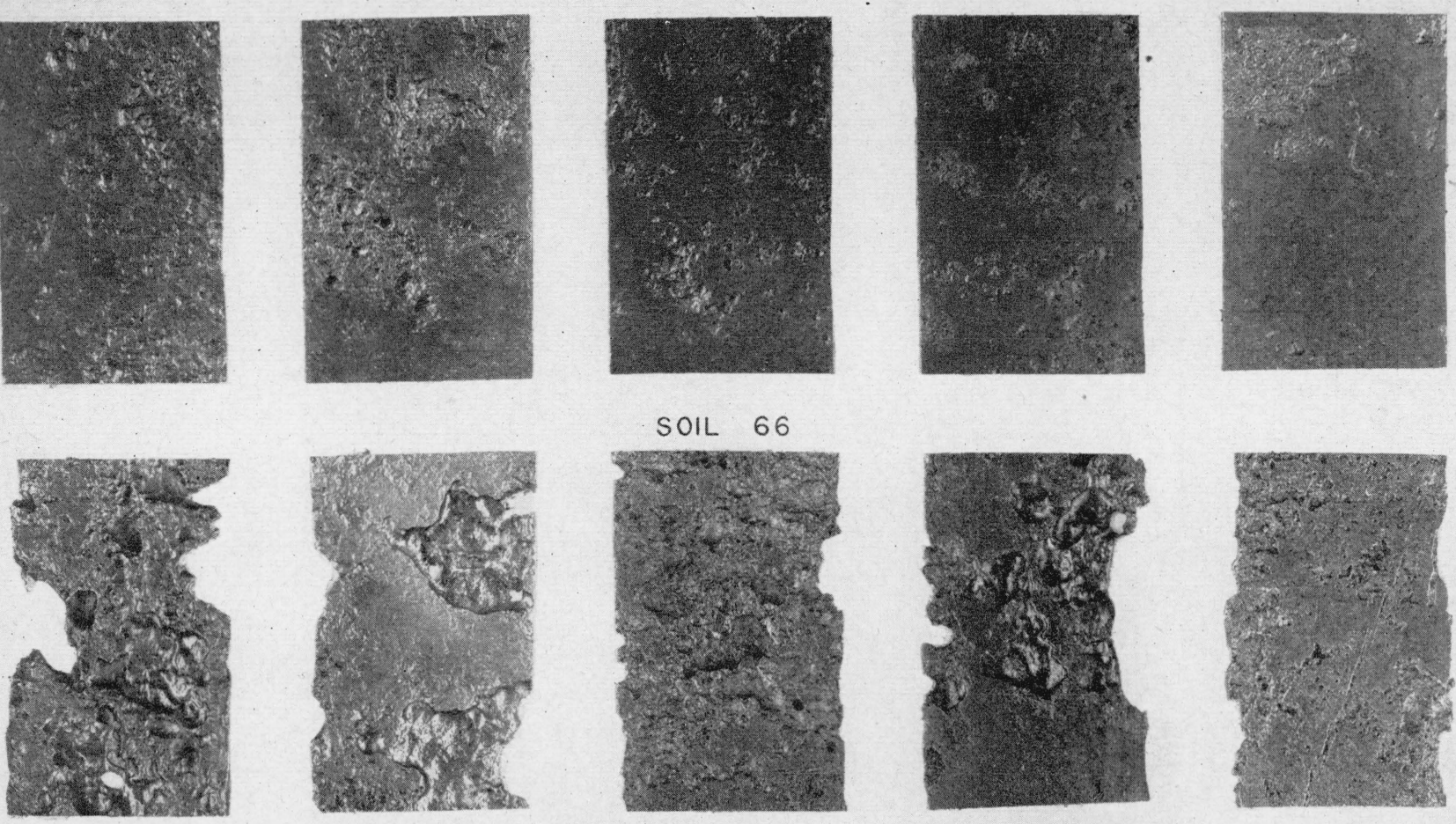

\section{SOIL 66}
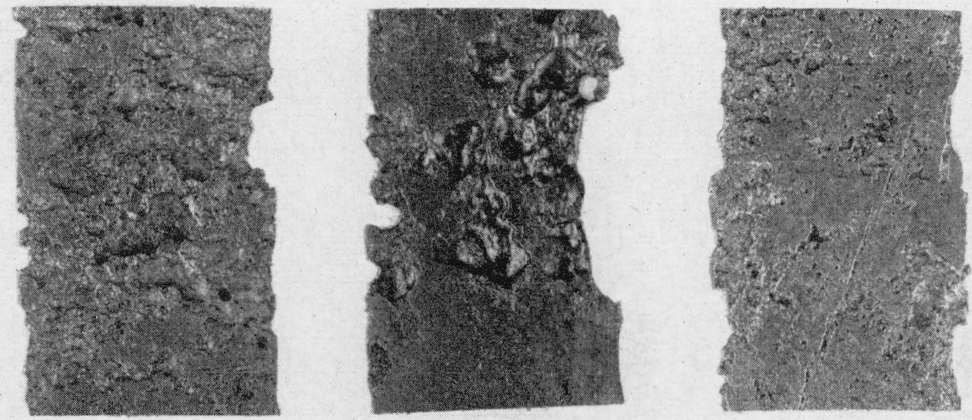

\section{SOIL 61}
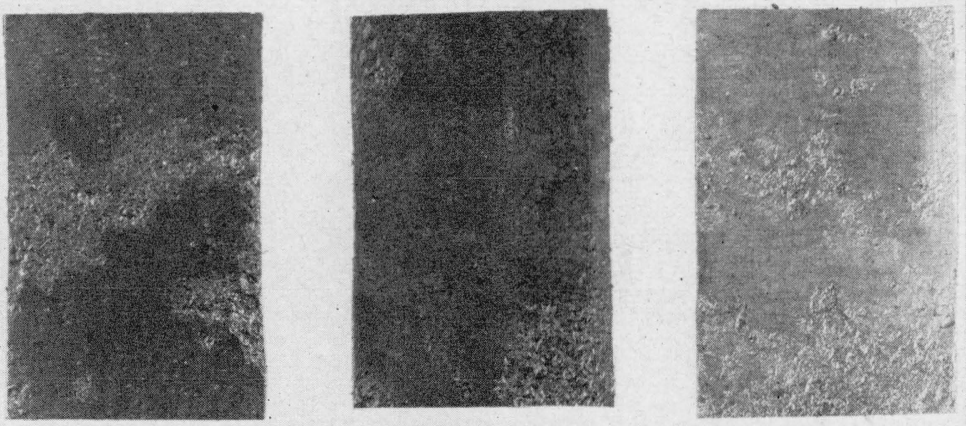

\section{SOIL 56}

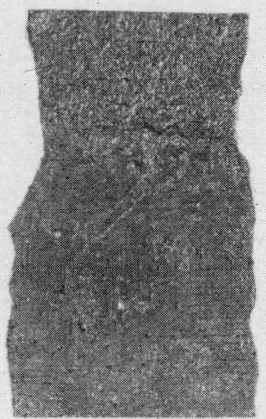

D

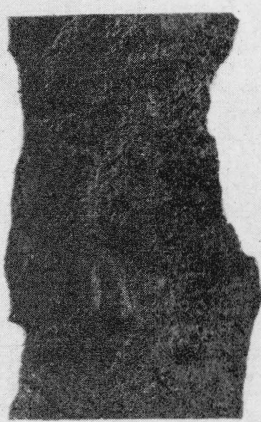

$E$

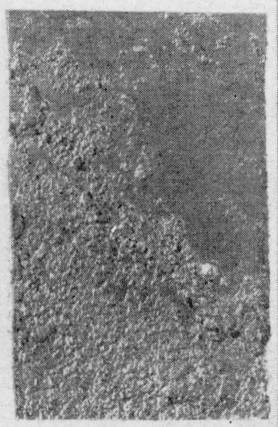

H

FIGURE 2. Corrosion of chromium-containing steels in several soil environments.

- C, Cr-Si-Cu-P steel, $1.02 \mathrm{Cr}, 0.42 \mathrm{Cu}$; KK, steel, $2.01 \mathrm{Cr}, 0.57 \mathrm{Mo}$; D, steel, $5.02 \mathrm{Cr}$ : E, steel, $4.67 \mathrm{Cr}$, 0.51 Mo; H, steel, $5.76 \mathrm{Cr}, 0.43 \mathrm{Cr}$. Soil 55 , well oxidized. acid silt loam deficient in soluble salts; soil 66 , fairly well aerated loam containing a high concentration of soluble material; soil 61 , poorly aerated clay containing a moderate amount of soluble material; soil 56 , very poorly aerated heavy clay containing a high concentration of soluble salts. 
TABLE 2. Loss in weight of alloy irons and steels in different soils

[A verage of two specimens, in ounces per square foot]

\begin{tabular}{|c|c|c|c|c|c|c|c|c|c|c|c|c|c|c|c|c|c|}
\hline \multirow[b]{3}{*}{$\begin{array}{l}\text { Identi- } \\
\text { fication }\end{array}$} & \multirow[b]{3}{*}{ Material ${ }^{a}$} & \multirow{3}{*}{$\begin{array}{l}\text { Aver- } \\
\text { age } \\
\text { expo- } \\
\text { sure }\end{array}$} & \multicolumn{15}{|c|}{ Aeration, test site number and soil type $b$} \\
\hline & & & \multicolumn{4}{|c|}{ Good aeration } & \multicolumn{3}{|c|}{ Fair aeration } & \multicolumn{3}{|c|}{ Poor aeration } & \multicolumn{5}{|c|}{ Very poor aeration } \\
\hline & & & $\begin{array}{c}53 \\
\text { Cecil } \\
\text { clay } \\
\text { loam }\end{array}$ & \begin{tabular}{|c|}
55 \\
\\
Hagers- \\
town \\
loam
\end{tabular} & $\begin{array}{c}62 \\
\begin{array}{c}\text { Susque- } \\
\text { hanna } \\
\text { clay }\end{array}\end{array}$ & $\begin{array}{l}65 \\
\text { Chino } \\
\text { silt } \\
\text { loam }\end{array}$ & $\begin{array}{c}64 \\
\begin{array}{c}\text { Docas } \\
\text { clay }\end{array}\end{array}$ & $\begin{array}{c}60 \\
\text { Mohave } \\
\text { fine } \\
\text { gravelly } \\
\text { loam }\end{array}$ & $\begin{array}{c}70 \\
\text { Merced } \\
\text { silt } \\
\text { loam }\end{array}$ & $\begin{array}{c}58 \\
\text { Muck }\end{array}$ & $\begin{array}{c}60 \\
\begin{array}{c}\text { Rifle } \\
\text { peat }\end{array}\end{array}$ & $\begin{array}{c}61 \\
\begin{array}{c}\text { Sharkey } \\
\text { clay }\end{array}\end{array}$ & $\begin{array}{c}51 \\
\begin{array}{c}\text { Acadia } \\
\text { clay }\end{array}\end{array}$ & $\begin{array}{c}56 \\
\begin{array}{c}\text { Lake } \\
\text { Charles } \\
\text { clay }\end{array}\end{array}$ & $\begin{array}{c}59 \\
\begin{array}{c}\text { Carlisle } \\
\text { muck }\end{array}\end{array}$ & $\begin{array}{c}63 \\
\text { Tidal } \\
\text { marsh }\end{array}$ & $\begin{array}{c}67 \\
\text { Cinders }\end{array}$ \\
\hline A & Open-hearth steel. . & $\left\{\begin{array}{r}y r \\
2.1 \\
4.0 \\
9.0 \\
11.1 \\
12.7\end{array}\right.$ & $\begin{array}{l}1.8 \\
3.2 \\
3.9 \\
3.4 \\
4.0\end{array}$ & $\begin{array}{l}2.0 \\
2.6 \\
3.8 \\
3.3 \\
4.0\end{array}$ & $\begin{array}{l}2.8 \\
3.7 \\
4.2 \\
5.0 \\
5.9\end{array}$ & $\begin{array}{l}4.6 \\
5.3 \\
7.2 \\
6.1 \\
8.2\end{array}$ & $\begin{array}{r}7.1 \\
7.4 \\
7.5 \\
\text { f } 19.0 \\
18.6\end{array}$ & $\begin{array}{r}8.3 \\
16.8 \\
4.6 \\
f 17.7 \\
19.9\end{array}$ & \begin{tabular}{r|}
5.0 \\
10.6 \\
17.9 \\
24.0 \\
25.7
\end{tabular} & $\begin{array}{r}5.7 \\
9.9 \\
16.9 \\
17.2 \\
18.1\end{array}$ & $\begin{array}{r}6.3 \\
9.5 \\
22.0 \\
15.8 \\
21.7\end{array}$ & $\begin{array}{l}2.6 \\
5.4 \\
4.3 \\
7.3 \\
8.1\end{array}$ & $\begin{array}{c}11.6 \\
d \bar{d} 19.1 \\
-\cdots . . .\end{array}$ & $\begin{array}{r}14.4 \\
18.4 \\
28.0 \\
48.1 \\
\mathrm{D}(53)\end{array}$ & $\begin{array}{r}1.5 \\
4.2 \\
9.9 \\
9.5 \\
11.1\end{array}$ & $\begin{array}{r}3.6 \\
c 6.2 \\
c 8.9 \\
16.9 \\
16.5\end{array}$ & $\begin{array}{r}12.0 \\
34.3 \\
\cdot \mathrm{D}(36) \\
37.8 \\
\mathrm{D}(42)\end{array}$ \\
\hline 0 & Open-hearth iron; $0.45 \mathrm{Cu}, 0.07 \mathrm{Mo}$ & $\left\{\begin{array}{r}2.1 \\
4.0 \\
9.0 \\
11.1 \\
12.7\end{array}\right.$ & $\begin{array}{l}2.1 \\
2.9 \\
3.4 \\
3.7 \\
3.7\end{array}$ & $\begin{array}{l}2.0 \\
2.8 \\
4.7 \\
3.7 \\
3.3\end{array}$ & $\begin{array}{l}3.0 \\
3.6 \\
4.6 \\
5.0 \\
5.2\end{array}$ & $\begin{array}{l}5.0 \\
5.0 \\
6.4 \\
5.3 \\
8.9\end{array}$ & $\begin{array}{r}8.0 \\
8.0 \\
6.4 \\
13.3 \\
18.5\end{array}$ & $\begin{array}{r}9.1 \\
11.6 \\
5.9 \\
16.4 \\
15.2\end{array}$ & $\begin{array}{r}5.4 \\
\text { f1. } \\
13.6 \\
22.9 \\
21.8\end{array}$ & $\begin{array}{r}5.8 \\
9.9 \\
17.3 \\
17.0 \\
17.5\end{array}$ & $\begin{array}{r}4.1 \\
7.4 \\
16.4 \\
21.1 \\
17.9\end{array}$ & $\begin{array}{l}3.0 \\
5.6 \\
4.8 \\
7.9 \\
8.6\end{array}$ & $\begin{array}{c}7.5 \\
\bar{d} 19.0 \\
-\cdots \\
-\cdots-. .\end{array}$ & $\begin{array}{r}12.4 \\
13.8 \\
28.4 \\
48.2 \\
\mathrm{D}(53)\end{array}$ & $\begin{array}{r}1.3 \\
2.9 \\
7.8 \\
8.3 \\
10.1\end{array}$ & $\begin{array}{r}2.5 \\
4.7 \\
7.1 \\
11.6 \\
15.9\end{array}$ & $\begin{array}{l}33.8 \\
33.2 \\
25.1 \\
29.3 \\
30.5\end{array}$ \\
\hline $\mathrm{N}$ & Open-hearth iron; $0.54 \mathrm{Cu}, 0.13 \mathrm{Mo}$ & $\left\{\begin{array}{r}2.1 \\
4.0 \\
9.0 \\
11.1 \\
12.7\end{array}\right.$ & $\begin{array}{l}2.0 \\
3.0 \\
3.3 \\
3.5 \\
3.8\end{array}$ & $\begin{array}{l}1.9 \\
2.7 \\
4.6 \\
3.5 \\
3.4\end{array}$ & $\begin{array}{l}3.0 \\
3.7 \\
4.7 \\
5.2 \\
5.3\end{array}$ & $\begin{array}{l}4.6 \\
5.0 \\
6.7 \\
5.5 \\
8.1\end{array}$ & $\begin{array}{r}8.0 \\
6.6 \\
5.8 \\
14.7 \\
18.0\end{array}$ & $\begin{array}{r}7.4 \\
12.0 \\
f 6.9 \\
f 20.5 \\
15.1\end{array}$ & $\begin{array}{r}4.8 \\
\text { f } 10.2 \\
15.0 \\
20.3 \\
20.0\end{array}$ & $\begin{array}{r}5.5 \\
9.4 \\
17.0 \\
17.1 \\
17.0\end{array}$ & $\begin{array}{r}4.8 \\
8.2 \\
14.5 \\
20.0 \\
20.8\end{array}$ & $\begin{array}{l}2.7 \\
5.6 \\
4.6 \\
7.5 \\
8.6\end{array}$ & $\begin{array}{c}7.2 \\
\bar{d} 18.8 \\
-\cdots\end{array}$ & $\begin{array}{r}13.0 \\
17.4 \\
33.7 \\
45.2 \\
\mathrm{D}(50)\end{array}$ & $\begin{array}{l}1.4 \\
2.9 \\
7.6 \\
7.9 \\
7.4\end{array}$ & $\begin{array}{r}3.0 \\
4.7 \\
7.2 \\
9.1 \\
11.7\end{array}$ & $\begin{array}{l}20.9 \\
27.7 \\
21.9 \\
27.5 \\
29.5\end{array}$ \\
\hline $\mathrm{J}$ & Copper-nickel steel; $0.95 \mathrm{Cu}, 0.52 \mathrm{Ni}$ & $\left\{\begin{array}{r}2.1 \\
4.0 \\
9.0 \\
11.1 \\
12.7\end{array}\right.$ & $\begin{array}{l}0.8 \\
1.3 \\
2.4 \\
2.8 \\
3.0\end{array}$ & $\begin{array}{l}1.2 \\
1.8 \\
3.5 \\
2.6 \\
2.6\end{array}$ & $\begin{array}{l}2.4 \\
3.3 \\
4.0 \\
5.4 \\
5.5\end{array}$ & $\begin{array}{l}3.4 \\
5.0 \\
6.2 \\
4.7 \\
8.8\end{array}$ & $\begin{array}{r}9.0 \\
6.0 \\
4.7 \\
17.7 \\
23.2\end{array}$ & $\begin{array}{r}7.3 \\
10.4 \\
8.2 \\
17.8 \\
25.5\end{array}$ & $\begin{array}{r}4.2 \\
\text { r7.6 } \\
17.3 \\
22.7 \\
20.0\end{array}$ & $\begin{array}{r}5.2 \\
10.6 \\
16.0 \\
17.6 \\
18.7\end{array}$ & $\begin{array}{r}5.3 \\
8.6 \\
18.8 \\
20.1 \\
14.3\end{array}$ & $\begin{array}{l}2.3 \\
4.8 \\
3.9 \\
6.7 \\
7.9\end{array}$ & $\begin{array}{c}7.0 \\
d \bar{d} 18.1 \\
-\cdots\end{array}$ & $\begin{array}{l}14.0 \\
19.2 \\
34.6 \\
49.5 \\
53.9\end{array}$ & $\begin{array}{l}1.6 \\
2.6 \\
5.5 \\
8.2 \\
8.5\end{array}$ & $\begin{array}{r}c 2.5 \\
3.5 \\
7.0 \\
7.8 \\
9.3\end{array}$ & $\begin{array}{r}20.3 \\
35.1 \\
30.4 \\
28.2 \\
\bullet 17.4\end{array}$ \\
\hline B \& & Nickel-copper steel; $1.96 \mathrm{Ni}, 1.01 \mathrm{Cu}_{-}$- & $\left\{\begin{array}{r}2.1 \\
4.0 \\
9.0 \\
11.1 \\
12.7\end{array}\right.$ & $\begin{array}{l}0.6 \\
1.1 \\
2.8 \\
2.4 \\
3.2\end{array}$ & $\begin{array}{l}0.8 \\
1.2 \\
2.6 \\
2.4 \\
3.1\end{array}$ & $\begin{array}{l}2.1 \\
2.9 \\
2.9 \\
5.1 \\
8.2\end{array}$ & $\begin{array}{r}4.9 \\
5.0 \\
7.6 \\
5.4 \\
10.8\end{array}$ & $\begin{array}{r}6.6 \\
4.9 \\
7.1 \\
\text { f.1.2 } \\
14.4\end{array}$ & $\begin{array}{r}8.9 \\
11.4 \\
3.1 \\
f 17.4 \\
19.8\end{array}$ & \begin{tabular}{r|}
3.9 \\
7.8 \\
18.4 \\
26.8 \\
29.6
\end{tabular} & $\begin{array}{r}6.2 \\
11.0 \\
17.7 \\
18.8 \\
20.8\end{array}$ & $\begin{array}{r}6.4 \\
9.6 \\
24.1 \\
17.0 \\
21.0\end{array}$ & $\begin{array}{l}2.0 \\
3.9 \\
3.2 \\
6.8 \\
7.6\end{array}$ & $\begin{array}{c}7.4 \\
d 20.2 \\
-\cdots\end{array}$ & $\begin{array}{r}13.0 \\
19.5 \\
31.2 \\
45.9 \\
\mathrm{D}(50)\end{array}$ & $\begin{array}{l}1.4 \\
2.4 \\
7.2 \\
7.8 \\
9.4\end{array}$ & $\begin{array}{r}2.3 \\
3.4 \\
8.9 \\
7.3 \\
11.7\end{array}$ & $\begin{array}{r}23.0 \\
44.3 \\
\mathrm{D}(49) \\
31.9 \\
39.0\end{array}$ \\
\hline C & Cr-Si-Cu-P steel; $1.02 \mathrm{Cr}, 0.42 \mathrm{Cu}_{-.-}$ & $\left\{\begin{array}{r}2.1 \\
4.0 \\
9.0 \\
11.1 \\
12.7\end{array}\right.$ & $\begin{array}{l}1.5 \\
2.4 \\
3.3 \\
2.9 \\
3.6\end{array}$ & $\begin{array}{l}1.3 \\
2.3 \\
3.0 \\
2.7 \\
3.3\end{array}$ & $\begin{array}{l}1.9 \\
3.0 \\
3.8 \\
4.7 \\
5.5\end{array}$ & $\begin{array}{r}4.4 \\
5.4 \\
11.0 \\
9.9 \\
11.4\end{array}$ & $\begin{array}{r}4.9 \\
5.1 \\
5.7 \\
10.6 \\
7.6\end{array}$ & $\begin{array}{r}6.9 \\
13.6 \\
3.9 \\
\text { f } 12.3 \\
17.6\end{array}$ & $\begin{array}{r}5.4 \\
9.8 \\
15.8 \\
28.1 \\
\mathrm{D}(33)\end{array}$ & $\begin{array}{r}4.4 \\
9.0 \\
16.7 \\
18.0 \\
18.7\end{array}$ & $\begin{array}{r}5.8 \\
10.2 \\
24.9 \\
18.5 \\
18.0\end{array}$ & $\begin{array}{l}2.4 \\
4.6 \\
3.6 \\
7.1 \\
7.1\end{array}$ & $\begin{array}{r}9.2 \\
d 19.6 \\
-. .-\end{array}$ & $\begin{array}{r}12.5 \\
20.8 \\
28.1 \\
44.0 \\
\mathrm{D}(49)\end{array}$ & $\begin{array}{l}1.1 \\
2.5 \\
7.8 \\
7.5 \\
8.5\end{array}$ & $\begin{array}{r}2.4 \\
4.1 \\
\circ 5.8 \\
7.9 \\
7.8\end{array}$ & $\begin{array}{r}17.7 \\
13.9 \\
26.3 \\
25.2 \\
\mathrm{D}(31)\end{array}$ \\
\hline K K & $2.01 \%$ chromium steel with $0.57 \mathrm{Mo}$ & $\left\{\begin{array}{r}2.1 \\
4.0 \\
9.0 \\
11.1 \\
12.7\end{array}\right.$ & $\begin{array}{l}1.6 \\
2.2 \\
2.9 \\
3.0 \\
3.5\end{array}$ & $\begin{array}{l}1.6 \\
2.4 \\
4.7 \\
2.8 \\
2.5\end{array}$ & $\begin{array}{l}2.4 \\
3.0 \\
4.3 \\
3.8 \\
4.7\end{array}$ & $\begin{array}{l}4.2 \\
4.5 \\
7.7 \\
7.3 \\
9.1\end{array}$ & $\begin{array}{l}4.9 \\
5.4 \\
4.6 \\
8.5 \\
8.8\end{array}$ & $\begin{array}{r}7.2 \\
12.3 \\
f 6.0 \\
f 18.9 \\
14.0\end{array}$ & \begin{tabular}{r|}
5.4 \\
9.7 \\
13.5 \\
26.2 \\
20.6
\end{tabular} & $\begin{array}{r}3.3 \\
8.4 \\
12.9 \\
13.6 \\
14.0\end{array}$ & $\begin{array}{r}3.8 \\
6.0 \\
13.8 \\
18.5 \\
15.3\end{array}$ & $\begin{array}{l}2.4 \\
4.7 \\
4.1 \\
6.4 \\
6.6\end{array}$ & $\begin{array}{c}7.9 \\
d 17.9 \\
-0 .\end{array}$ & $\begin{array}{r}9.0 \\
14.5 \\
28.9 \\
34.3 \\
34.2\end{array}$ & $\begin{array}{l}1.2 \\
2.5 \\
4.8 \\
7.9 \\
7.3\end{array}$ & $\begin{array}{l}1.8 \\
3.1 \\
4.9 \\
5.3 \\
6.7\end{array}$ & $\begin{array}{r}18.1 \\
16.4 \\
15.0 \\
20.4 \\
13.7\end{array}$ \\
\hline $\mathrm{D}$ & $5.02 \%$ chromium steel... & $\left\{\begin{array}{r}2.1 \\
4.0 \\
9.0 \\
11.1 \\
12.7\end{array}\right.$ & $\begin{array}{l}0.9 \\
1.3 \\
2.0 \\
2.1 \\
2.8\end{array}$ & $\begin{array}{l}0.7 \\
1.1 \\
1.7 \\
1.7 \\
1.6\end{array}$ & $\begin{array}{l}0.7 \\
1.2 \\
1.8 \\
2.2 \\
2.5\end{array}$ & $\begin{array}{l}2.3 \\
2.2 \\
3.6 \\
2.8 \\
3.5\end{array}$ & $\begin{array}{r}4.5 \\
4.4 \\
4.4 \\
10.0 \\
7.2\end{array}$ & $\begin{array}{r}5.8 \\
12.1 \\
f 3.5 \\
f 13.5 \\
14.7\end{array}$ & $\begin{array}{r}4.9 \\
10.0 \\
19.1 \\
29.5 \\
022.8\end{array}$ & $\begin{array}{l}4.1 \\
5.9 \\
7.5 \\
7.2 \\
7.8\end{array}$ & $\begin{array}{r}4.5 \\
6.6 \\
14.8 \\
14.6 \\
17.2\end{array}$ & $\begin{array}{l}0.6 \\
1.6 \\
1.1 \\
2.2 \\
1.9\end{array}$ & $\begin{array}{c}6.6 \\
-17.6 \\
-\cdots . .-\end{array}$ & $\begin{array}{r}9.4 \\
17.9 \\
28.8 \\
43.1 \\
\mathrm{D}(48)\end{array}$ & $\begin{array}{l}0.4 \\
.9 \\
3.0 \\
4.8 \\
3.1\end{array}$ & $\begin{array}{l}\text { 1. } 8 \\
3.8 \\
5.6 \\
6.0 \\
9.2\end{array}$ & $\begin{array}{r}17.1 \\
18.1 \\
12.2 \\
7.9 \\
10.3\end{array}$ \\
\hline E & $4.67 \%$ chromium steel with $0.51 \mathrm{Mo}_{-.}$ & $\left\{\begin{array}{r}2.1 \\
4.0 \\
9.0 \\
11.1 \\
12.7\end{array}\right.$ & $\begin{array}{l}0.9 \\
1.6 \\
2.0 \\
2.3 \\
2.9\end{array}$ & $\begin{array}{l}0.6 \\
1.2 \\
1.7 \\
1.6 \\
1.7\end{array}$ & $\begin{array}{l}0.7 \\
1.1 \\
2.0 \\
2.3 \\
2.4\end{array}$ & $\begin{array}{l}2.5 \\
2.1 \\
3.3 \\
2.1 \\
3.8\end{array}$ & $\begin{array}{r}4.2 \\
5.2 \\
4.2 \\
10.2 \\
6.4\end{array}$ & 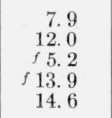 & \begin{tabular}{r|}
5.2 \\
9.9 \\
19.5 \\
26.0 \\
$\circ 18.1$
\end{tabular} & $\begin{array}{l}3.9 \\
7.2 \\
6.4 \\
8.1 \\
9.5\end{array}$ & $\begin{array}{r}4.1 \\
6.2 \\
13.2 \\
14.9 \\
15.0\end{array}$ & $\begin{array}{l}0.9 \\
1.8 \\
1.4 \\
2.4 \\
2.6\end{array}$ & $\begin{array}{c}7.1 \\
d 16.2 \\
-\cdots . .-\end{array}$ & $\begin{array}{r}9.6 \\
16.3 \\
28.2 \\
36.8 \\
\mathrm{D}(41)\end{array}$ & $\begin{array}{l}0.4 \\
.8 \\
2.5 \\
4.9 \\
3.4\end{array}$ & $\begin{array}{l}1.7 \\
5.2 \\
5.3 \\
5.4 \\
9.0\end{array}$ & $\begin{array}{r}12.2 \\
\text { r11. } \\
11.2 \\
5.7 \\
8.3\end{array}$ \\
\hline $\mathrm{H}$ & $5.76 \%$ chromium steel with $0.43 \mathrm{Mo}_{\ldots}$ & $\left\{\begin{array}{r}2.1 \\
4.0 \\
9.0 \\
11.1 \\
12.7\end{array}\right.$ & $\begin{array}{r}\bullet 0.8 \\
1.4 \\
1.9 \\
2.0 \\
2.7\end{array}$ & $\begin{array}{l}0.7 \\
1.1 \\
2.0 \\
1.8 \\
1.8\end{array}$ & $\begin{array}{r}0.7 \\
1.3 \\
1.9 \\
2.4 \\
\odot 2.1\end{array}$ & $\begin{array}{l}2.5 \\
2.2 \\
3.7 \\
2.1 \\
3.6\end{array}$ & $\begin{array}{l}5.9 \\
5.0 \\
4.0 \\
9.0 \\
8.5\end{array}$ & $\begin{array}{r}8.4 \\
14.5 \\
5.0 \\
12.2 \\
15.2\end{array}$ & \begin{tabular}{r|}
5.0 \\
10.2 \\
17.6 \\
29.1 \\
$c 31.0$
\end{tabular} & $\begin{array}{r}3.5 \\
\circ 6.8 \\
6.1 \\
07.1\end{array}$ & $\begin{array}{r}4.6 \\
6.2 \\
14.2 \\
19.0 \\
14.4\end{array}$ & $\begin{array}{r}0.8 \\
1.6 \\
.1 .0 \\
1.9 \\
1.8\end{array}$ & $\begin{array}{c}{ }^{\circ} 8.3 \\
\bar{d} 16.7 \\
-\end{array}$ & 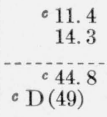 & $\begin{array}{l}0.2 \\
.7 \\
2.2 \\
4.4 \\
2.4\end{array}$ & $\begin{array}{r}\circ 1.7 \\
5.4 \\
6.4 \\
6.4 \\
8.0\end{array}$ & $\begin{array}{r}12.6 \\
\text { f } 12.9 \\
8.9 \\
7.8 \\
10.2\end{array}$ \\
\hline
\end{tabular}

a See table 1 for composition of materials.

b See reference $[1]$ for properties of soil
¿Data for 1 specimen d A verage of 8 specimens.

Destos corrosion. The number in parentheses is the observed loss in weight. 
TABLE 3. Maximum penetration of alloy irons and steels

[A verage of two specimens, in mils]

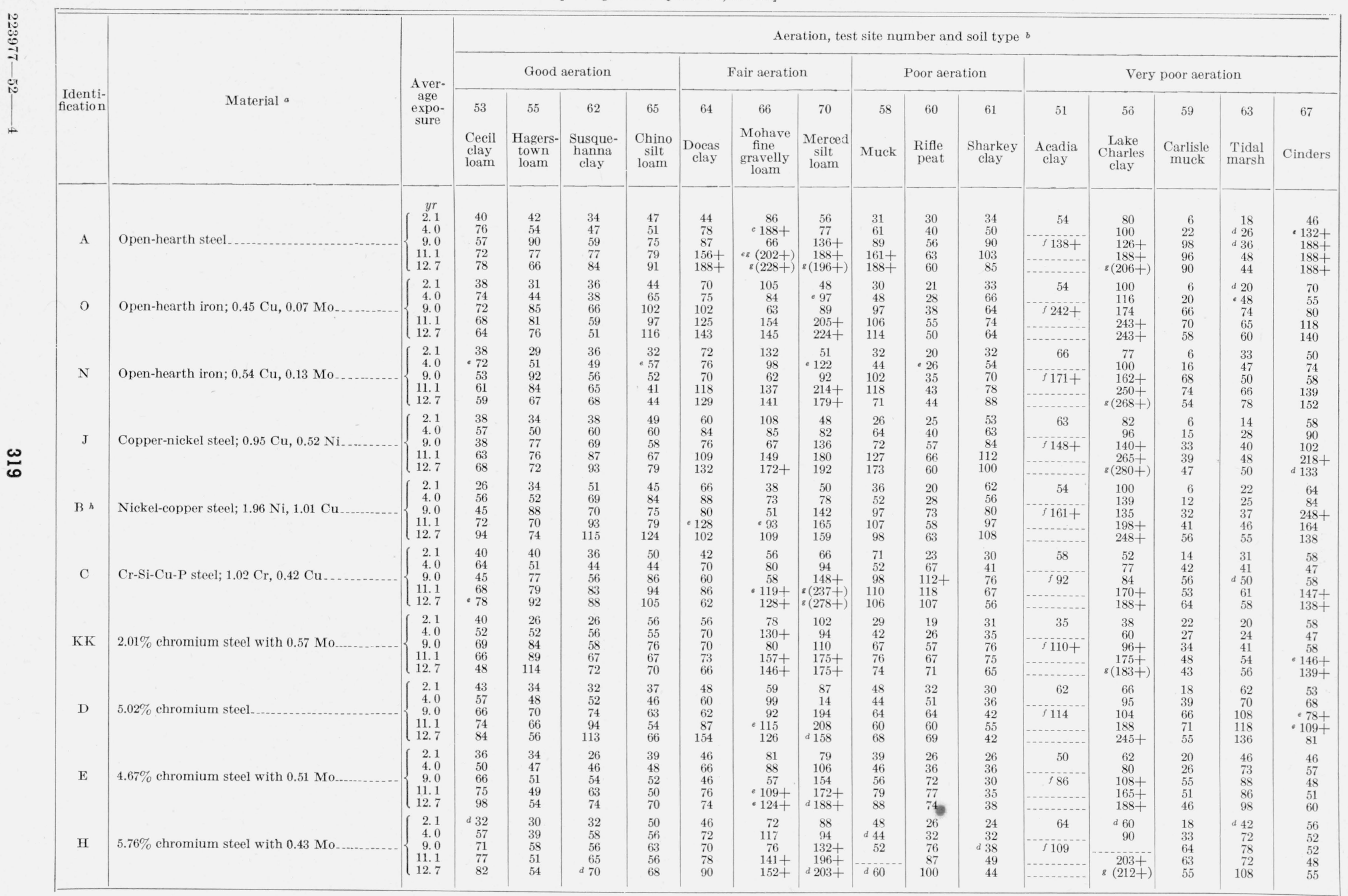

a See table 1 for composition of materials

$b$ See reference [1] for properties of soils.
$c$ The plus sign indicates 1 or more specimens contained holes because of corrosion.

- Data for the individual specimens differed from the average by more than $50 \%$.

A verage of 8 specimens.

- Numbers in parentheses are pit depths adjusted for perforation by multiplying the average penetration

$h$ The mill seale was not removed from these specimens. 
sidered by Denison and Hobbs to be characteristic of soils and Logan [2] showed that it varied directly with the aeration. Adjusted values of pit depths recorded in table 3 are enclosed in parentheses.

The over-all behavior of materials and the effect of the various alloying constituents on the corrosion of iron and steel in the soils is indicated by the weight loss and pit depth-time curves shown in figures 3 and 4. In preparing these curves, the values for weight loss and pit depth for each material in all of the soils, except $51,{ }^{2}$ were averaged for each period of exposure. The logarithms of these average values were then plotted against the logarithms of the periods of exposure.

The curves shown in figure 3 and 4 conform to the equations

$$
\begin{gathered}
P=k T^{n} \\
W=k^{\prime} T^{u}
\end{gathered}
$$

wnere $P$ is the depth of the deepest pit at the time $T$ and $W$ is the weight loss at the time $T$.

Converting to logarithms,

$$
\begin{aligned}
& \log P=n \log T+\log k \\
& \log W=u \log T+\log k^{\prime} .
\end{aligned}
$$

Hence $n(u)$ is the slope of the line and $k\left(k^{\prime}\right)$ is the intercept on the $\log P(W)$ axis.

Equations 1 and 2 were derived originally by Logan, Ewing, and Denison [5], and by Martin [6], respectively.

The constants of the equations, expressing the initial corrosion rate of the materials and the change in the rate with time, were calculated by the method of least squares for each material in each soil. By means of these constants, values of the average weight loss and pitting of each material in all of the soils were calculated for the maximum periods of exposure. These values, together with the constants of the equations and their standard errors, are tabulated in table 4.

In order to estimate the probability that the weight loss or pitting of each material was significantly different from the corresponding values for plain steel, taken as the reference material, the standard $t$-test was applied, and from the calculated values of $t$, the probability of the differences being due to chance was obtained [7].

The weight loss and pitting data for the coppermolybdenum open-hearth irons $\mathrm{O}$ and $\mathrm{N}$ and for the nickel-copper steels $J$ and $B$, presented in figure 3 and in table 4 show that these alloys corroded slightly less than the plain steel A. How ever, the probability is high that several of the observed differences are due to chance. Because mill scale was not removed from the specimens of steel B before burial, the data recorded for this steel cannot be taken as truly representing the effect of additions of 2 percent of nickel and 1 percent of copper on the corrosion of steel in these soils. 2 The data for the specimens in soil 51 were omitted because data were a vailable
or two periods only.
The average depths of the deepest pits on these materials, given by the values of the constant $k$ ( $y$-intercept), indicate that the low-alloy steels had a greater initial pitting rate than the plain steel. However, as the exposure increased, the rate of pitting of the alloy steels diminished more rapidly than the rate for the plain steel so that after $13 \mathrm{yr}$ the order of the materials was reversed.

The weight loss and pit depth data for the group of chromium and chromium-molybdenum steels, C, KK, D, E, and H, (fig. 4 and table 4) exhibit similar but somewhat greater effects of the alloying constituents than the copper-molybdenum and coppernickel irons and steels. Chromium reduced the weight losses in a fairly regular manner, but increased the initial pitting rates of the steels. However, the rates of pitting of the alloy steels decreased more rapidly with time than the rate for plain steel.

The separate effects of chromium and molybdenum on the pitting of steel are difficult to determine because the chromium steels also generally contain molybdenum. It will be observed that steels $\mathrm{C}$ and $\mathrm{D}$, containing 1 and 5 percent of chromium, respectively, had pits of about the same depth. Within this range chromium alone in excess of 1 or 2 percent does not appreciably increase the resistance of the material to pitting. On the other hand, the influence of molybdenum in reducing pitting is quite definite because all of the chromium steels containing molybdenum, KK, E, and $\mathrm{H}$, had shallower pits than the straight chromium steel D.

The pit-depth-time curves, figures 3 and 4 , indicate that the change in the rate of pitting with time depends on the composition of the steel. In general, the greater the amount of nickel, chromium and molybdenum in the steels, the greater was the change in the rate of pitting of the steels with time. It may be assumed that the alloying constituents induced the formation of corrosion products, which were effective in diminishing the rates of pitting of the alloy steels with time. The results of a previous study of the effect of corrosion products on the rate of pitting of steel [8] suggests a probable explanation for the observed differences in corrosion rate. In that study it was observed that in soils in which the corrosion products of ferrous metals diffused outward into the soil, the rate of pitting changed relatively little with time, but in soils in which the corrosion products remained in close contact with the corroding surface, the rate of pitting diminished with time, often becoming negligible after relatively short periods of exposure.

The conclusions that can be drawn from the data in table 4 and in figures 3,4 , and 5 are necessarily limited because these data indicate only the average behavior of the materials under a wide variety of environmental conditions. Whether a particular alloy is more resistant to corrosion than plain steel in a specific soil environment obviously cannot be predicted from these average values. Although the average rates of pitting of the alloy steels decrease more rapidly than the pitting rate of plain steel, it should be recalled that this effect is a consequence 
of the environment as well as of the material. For example, in a very poorly aerated soil, corrosion. products would tend to diffuse and migrate outward into the soil rather than to form protective layers enclosing pits. Under such conditions, the higher initial rate of pitting of the alloy steels would tend to be maintained.

For comparison of the behavior of the materials under different environmental conditions, the corrosion data for the soils classified according to aeration (tables 2 and 3 ) were calculated on a relative basis for each material for all periods of exposure, the weight losses and pit depths of the reference steel A being taken as 100 percent. The averages of these values for all periods and for all soils in the same environmental groups are given in table 5. Because the data for soil 51 are incomplete, they were not included in calculating the relative values.

The relative corrodibility of the low-alloy irons and steels as measured by weight loss was not affected appreciably by differences in the aeration of the soils. However, the 4- to 6-percent chromium steels were deeply pitted in all of the very poorly aerated soils, except cinders. These steels had higher initial rates of pitting than plain steel, but the rates decreased considerably with time in most of the soils. In the poorly aerated soils, however, this high rate of pitting continued throughout the exposure period, probably because conditions were not favorable to the formation of tubercles, which would have diminished the pitting rate. In contrast is the behavior of these steels in cinders (table 3 and fig. 5), where the initial pitting of all the steels was about the same. The pitting of the plain steel continued at a high rate for the entire exposure period, but most of the pitting of the 4 - to 6-percent chromium steels occurred during the first 4 yr of the test, there being only slight increases in pit depth of these steels after that time. This is even more marked in the case of the steels containing molybdenum in addition to chromium (E and $\mathrm{H}$ ), in which there was practically no additional pitting after the first $4 \mathrm{yr}$.

Steels containing copper and molybdenum also show more resistance to pitting in cinders after $4 \mathrm{yr}$ of exposure than the plain steel, although to a lesser extent than the 4- to 6-percent-chromium steels.

\section{Summary}

This report contains the results of measurements of corrosion made on several low-alloy irons and steels after exposure to different soils for periods up to $13 \mathrm{yr}$. Empirical equations fitted to weight loss and pit-depth-time curves permitted the initial rates of weight loss and pitting and the change in these rates with time to be evaluated. The general effect of the alloying elements was to reduce the initial rate of corrosion of the alloys as measured by weight loss but to increase the initial rate of pitting. Except in very poorly aerated soils, the rate of pitting of the alloy steels diminished more rapidly with time than the rate of pitting of plain steel, with the result that the maximum depths of pits after the maximum period of exposure were less on the alloy steels than on the plain steels. Chromium was observed to have the most pronounced effect on weight loss, but for maximum reduction in pitting, molybdenum also was necessary. Chromium and molybdenum were particularly effective in reducing the corrosion of alloy steels exposed to cinders.

The field tests described in this paper were planned and installed, and until 1946 were conducted under the supervision of K. H. Logan.

The writers gratefully acknowledge the cooperation of O. B. Ellis, Research Laboratory, Armco Steel Co. and of C. P. Larrabee, Research Laboratory, United States Steel Co. in making available their equipment for cleaning the specimens by the sodium hydride process.

The authors also gratefully acknowledge the assistance received from the following organizations that cooperated in the project by providing the test sites and the labor required during the installation and removal of the test specimens: Water Department, Charleston, S. C.; Department of Water Works, Atlanta, Ga.; City of Meridian, Meridian, Miss.; New Orleans Public Service Co., New Orleans, La.; Sewerage and Water Board, New Orleans, La.; Gulf Oil Corp., Houston, Tex.; Water Department, Phoenix, Ariz.; Shell Oil Co., Inc., Wilmington, Calif.; Pacific Gas \& Electric Co., Bakersfield, Calif.; Union Oil Company of California, San Luis Obispo, Calif.; Milwaukee Gas \& Electric Co., Milwaukee, Wis.; City Light \& Water Utilities, Kalamazoo, Mich.; Columbia Engineering Corp., Columbus, Ohio; Sinclair Refining Co., Fort Worth, Tex.; Bureau of Water Supply, Baltimore, Md.

\section{References}

[1] Irving A. Denison and Melvin Romanoff, J. Research NBS 44, 47 (1950) RP2057.

[2] Kirk H. Logan, Underground corrosion, NBS Circular 450 (1945).

[3] H. L. Alexander, Iron \& Steel Eng. 24, 5, 44 (May 1947).

[4] I. A. Denison and R. B. Hobbs, J. Research NBS 13, 125 (1934) RP696.

[5] K. H. Logan, S. P. Ewing and I. A. Denison, Symposium on corrosion testing procedures, Am. Soc. Testing Mtls., Philadelphia, Pa. (1937).

[6] L. M. Martin, NBS Soil Corrosion Conference 1937 (unpublished).

[7] G. S. Eldredge, Section on statistical methods, p. 1083, Corrosion Handbook, (John Wiley \& Sons, New York, N. Y., 1948).

[8] I. A. Denison, Chemical aspects of underground corrosion and corrosion prevention, Monograph, Technical Section, Am. Gas Assn. (1948). 
TABLE 4. Calculated average values of weight loss and pit depth after 13 years of exposure and constants of the weight-loss and pit-depth equations a

\begin{tabular}{|c|c|c|c|c|c|c|c|c|c|c|c|c|c|c|c|c|c|c|c|c|c|}
\hline \multirow{3}{*}{$\begin{array}{l}\text { Identi- } \\
\text { fication }\end{array}$} & \multirow{3}{*}{ Material } & \multicolumn{10}{|c|}{ Weight loss } & \multicolumn{10}{|c|}{ Maximum penetration } \\
\hline & & \multirow{2}{*}{$\begin{array}{l}\text { Mean, } \bar{X} \\
\left(W_{T-13 y x}\right)\end{array}$} & \multirow{2}{*}{$\begin{array}{c}\text { Standard } \\
\text { error, } \bar{\sigma} \\
\left(W_{T-13 \mathrm{yr}}\right)\end{array}$} & \multicolumn{2}{|c|}{$\begin{array}{l}\text { Reduction in } \\
\text { weight loss as } \\
\text { compared with } \\
\text { control A }\end{array}$} & \multirow[t]{2}{*}{$t^{b}$} & \multirow{2}{*}{$\begin{array}{l}\text { Prob- } \\
\text { ability } \\
\text { of the } \\
\text { differ- } \\
\text { ence } \\
\text { being } \\
\text { due to } \\
\text { chance }\end{array}$} & \multirow[t]{2}{*}{$k^{\prime}$} & \multirow[t]{2}{*}{$\bar{\sigma} k^{\prime}$} & \multirow[t]{2}{*}{$u$} & \multirow[t]{2}{*}{$\bar{\sigma} u$} & \multirow{2}{*}{$\underset{\left(P_{T-13 \mathrm{yr}}\right)}{\operatorname{Mean}, \bar{X}}$} & \multirow{2}{*}{$\begin{array}{c}\text { Standard } \\
\text { error, } \bar{\sigma} \\
\left(P_{T=13 \mathrm{yr}}\right)\end{array}$} & \multicolumn{2}{|c|}{$\begin{array}{l}\text { Reduction in } \\
\text { maximum pit } \\
\text { depth as com- } \\
\text { pared with } \\
\text { control A }\end{array}$} & \multirow[t]{2}{*}{$t^{b}$} & \multirow{2}{*}{$\begin{array}{c}\text { Prob- } \\
\text { ability } \\
\text { of the } \\
\text { differ- } \\
\text { ence } \\
\text { being } \\
\text { due to } \\
\text { chance }\end{array}$} & \multirow[t]{2}{*}{$k$} & \multirow[t]{2}{*}{$\bar{\sigma}_{k}$} & \multirow[t]{2}{*}{$n$} & \multirow[t]{2}{*}{$\bar{\sigma}_{n}$} \\
\hline & & & & $\bar{X}_{1}-\bar{X}_{2}$ & $\begin{array}{l}\text { Rela- } \\
\text { tive } \\
\text { basis }\end{array}$ & & & & & & & & & $\bar{X}_{1}-\bar{X}_{2}$ & $\begin{array}{c}\text { Rela- } \\
\text { tive } \\
\text { basis }\end{array}$ & & & & & & \\
\hline \multirow{2}{*}{$\begin{array}{l}\mathrm{A} \\
\mathrm{O}\end{array}$} & Open-hearth steel & $o z / f t^{2}$ & $0 z / \delta t^{2}$ & $o z / f t^{2}$ & Percent & & Percent & $\begin{array}{c}o z / f t^{2} \\
3.78\end{array}$ & $\begin{array}{l}o z / f t^{2} \\
0.52\end{array}$ & 0.60 & 0.07 & Mils $_{127}$ & Mils $_{9,3}$ & Mils & Percent & & Percent & $\begin{array}{l}\text { Mils } \\
28,8\end{array}$ & $\begin{array}{r}\text { Mils } \\
4.2\end{array}$ & 0.58 & \multirow{2}{*}{$\begin{array}{r}0.07 \\
.05\end{array}$} \\
\hline & $\begin{array}{l}\text { Open-hearth iron; } 0.45 \mathrm{Cu} \text {, } \\
0.07 \text { Mo. }\end{array}$ & & & 2.5 & 14 & 1.47 & 16 & 4.79 & .75 & .45 & .08 & 110 & & 17.3 & 14 & 1.64 & 12 & 31.4 & 2.9 & .49 & \\
\hline $\mathrm{N}$ & $\begin{array}{l}\text { Open-hearth iron; } 0.54 \mathrm{Cu} \text {, } \\
0.13 \mathrm{Mo}\end{array}$ & 15,2 & 0.8 & 2.5 & 14 & 1.74 & 10 & 4.02 & .45 & .52 & .03 & 102 & 7.7 & 25.1 & 20 & 2.09 & 2 & 33.2 & 5.0 & .44 & .08 \\
\hline $\mathrm{J}$ & $\begin{array}{l}\text { Copper-nickel } \\
\text { Cu, } 0.52 \mathrm{Ni} \text {. }\end{array}$ & 15.6 & .8 & 2.1 & 12 & 1.46 & 16 & 3.87 & .37 & .54 & .05 & 112 & 10.4 & 15.3 & 12 & 1. 09 & 29 & 30.8 & 5.8 & .50 & .10 \\
\hline B & $\begin{array}{l}\text { Nickel-copper } \\
\text { Ni, } 1.01 \text { Cu. }\end{array}$ & 17.3 & .6 & 0.4 & 2 & 0.30 & 77 & 3.93 & .25 & .58 & .03 & 110 & 3.6 & 17.1 & 13 & 1. 72 & 10 & 31.1 & 2.0 & .49 & .03 \\
\hline $\mathrm{C}$ & Cr-Si-Cu-P steel; $1.02 \mathrm{Cr}$, & 15.3 & .6 & 2.4 & 14 & 1.79 & 10 & 3.30 & .23 & .60 & .04 & 107 & 7.0 & 20.2 & 16 & 1.74 & 10 & 29.3 & 3.9 & .50 & .07 \\
\hline KK & $2.01 \%$ chromium steel with & 12.0 & .7 & 5.7 & 32 & 4. 10 & $<1$ & 3.27 & .02 & .51 & .03 & 93 & 5.5 & 33.4 & 26 & 3.10 & $<1$ & 30.3 & 3.6 & .44 & .06 \\
\hline$\underset{\mathrm{E}}{\mathrm{D}}$ & $\begin{array}{l}5.02 \% \text { chromium steel } \\
4.67 \% \text { chromium steel with } \\
0.51 \text { Mo. }\end{array}$ & $\begin{array}{l}10.7 \\
10.0\end{array}$ & $\begin{array}{l}.6 \\
.5\end{array}$ & $\begin{array}{l}7.0 \\
7.7\end{array}$ & $\begin{array}{l}40 \\
44\end{array}$ & $\begin{array}{l}5.22 \\
5.92\end{array}$ & $<1$ & $\begin{array}{l}2.85 \\
2.76\end{array}$ & $\begin{array}{l}.34 \\
.28\end{array}$ & $\begin{array}{l}.52 \\
.50\end{array}$ & .03 & $\begin{array}{r}100 \\
85\end{array}$ & $\begin{array}{l}3.0 \\
4.2\end{array}$ & $\begin{array}{l}24.4 \\
41.1\end{array}$ & $\begin{array}{l}19 \\
32\end{array}$ & $\begin{array}{l}2.50 \\
4.03\end{array}$ & $<2$ & $\begin{array}{l}33.5 \\
33.0\end{array}$ & $\begin{array}{l}1.9 \\
0.1\end{array}$ &. .44 & .03 \\
\hline $\mathrm{H}$ & $\begin{array}{l}5.76 \% \text { chromium steel with } \\
0.43 \mathrm{Mo} \text {. }\end{array}$ & 10.1 & 1.6 & 7.6 & 43 & 3.80 & $<1$ & 2.86 & .29 & .49 & .16 & 92 & 6.3 & 35.0 & 28 & 3.15 & $<1$ & 33.5 & 4.6 & .39 & .07 \\
\hline
\end{tabular}

a $W=k^{\prime} T^{u}, P=k T^{n}$, where $W$ is the weight loss at the time $T$, and $P$ is the depth of the deepest pit at the time $T$.

${ }^{b} t=\frac{\bar{X}_{1}-\bar{X}_{2}}{\sqrt{\sigma_{\bar{x}_{1}}^{2}+\sigma_{\bar{X}^{2}}}}$

TABLE_5. Effect of composition on the corrosion of low-alloy iron and steel specimens in soils classified according to aeration (maximum exposure 13 yrs.)

\begin{tabular}{|c|c|c|c|c|c|c|c|c|c|c|c|c|c|c|}
\hline \multirow[t]{2}{*}{ Identification } & \multirow{2}{*}{$\mathrm{Cr}$} & \multirow{2}{*}{$\mathrm{Ni}$} & \multirow{2}{*}{$\mathrm{Cu}$} & \multirow{2}{*}{ Mo } & Good & Fair & Poor & $\begin{array}{l}\text { Very } \\
\text { poor }\end{array}$ & $\begin{array}{c}\text { Very poor } \\
\text { cinders }\end{array}$ & Good & Fair & Poor & $\begin{array}{l}\text { Very } \\
\text { poor }\end{array}$ & $\begin{array}{l}\text { Very poor } \\
\text { cinders }\end{array}$ \\
\hline & & & & & \multicolumn{5}{|c|}{ A verage loss in weight $a$} & \multicolumn{5}{|c|}{ A verage maximum penetration $a$} \\
\hline 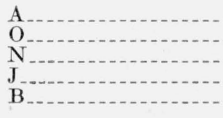 & $\begin{array}{c}0.049 \\
.02 \\
.02 \\
-.- \\
-.-\end{array}$ & $\begin{array}{r}0.034 \\
.15 \\
.14 \\
.52 \\
1.96\end{array}$ & $\begin{array}{l}0.052 \\
.45 \\
.54 \\
.95 \\
1.01\end{array}$ & $\begin{array}{r}0.07 \\
.13 \\
-\end{array}$ & $\begin{array}{r}100 \\
100 \\
100 \\
79 \\
79\end{array}$ & $\begin{array}{r}100 \\
95 \\
93 \\
98 \\
91\end{array}$ & $\begin{array}{r}100 \\
98 \\
97 \\
94 \\
99\end{array}$ & $\begin{array}{r}100 \\
84 \\
83 \\
81 \\
81\end{array}$ & $\begin{array}{r}100 \\
120 \\
92 \\
94 \\
127\end{array}$ & $\begin{array}{r}100 \\
100 \\
87 \\
96 \\
110\end{array}$ & $\begin{array}{r}100 \\
95 \\
96 \\
92 \\
81\end{array}$ & $\begin{array}{r}100 \\
82 \\
80 \\
102 \\
100\end{array}$ & $\begin{array}{r}100 \\
120 \\
119 \\
93 \\
95\end{array}$ & $\begin{array}{r}100 \\
75 \\
63 \\
72 \\
72\end{array}$ \\
\hline $\begin{array}{l}\mathrm{C} \\
\mathrm{K} K \\
\mathrm{D} \\
\mathrm{D} \\
\mathrm{E} \\
\mathrm{H}\end{array}$ & $\begin{array}{l}1.02 \\
2.01 \\
5.02 \\
4.67 \\
5.76\end{array}$ & $\begin{array}{r}0.22 \\
.07 \\
.09 \\
.09 \\
.17\end{array}$ & $\begin{array}{r}0.428 \\
.004 \\
.008 \\
.004 \\
.004\end{array}$ & $\begin{array}{r}.57 \\
-.51 \\
.43\end{array}$ & $\begin{array}{l}94 \\
90 \\
45 \\
46 \\
46\end{array}$ & $\begin{array}{l}83 \\
82 \\
77 \\
79 \\
85\end{array}$ & $\begin{array}{l}95 \\
80 \\
51 \\
53 \\
52\end{array}$ & $\begin{array}{l}76 \\
63 \\
58 \\
56 \\
56\end{array}$ & $\begin{array}{l}80 \\
66 \\
55 \\
40 \\
43\end{array}$ & $\begin{array}{r}101 \\
97 \\
96 \\
84 \\
88\end{array}$ & $\begin{array}{r}84 \\
91 \\
94 \\
83 \\
100\end{array}$ & $\begin{array}{r}116 \\
78 \\
83 \\
78 \\
84\end{array}$ & $\begin{array}{l}115 \\
103 \\
176 \\
149 \\
149\end{array}$ & $\begin{array}{l}64 \\
60 \\
64 \\
54 \\
59\end{array}$ \\
\hline
\end{tabular}

a Average for 5 periods of exposure, relative to open-hearth steel $(\mathrm{A})=100$ 

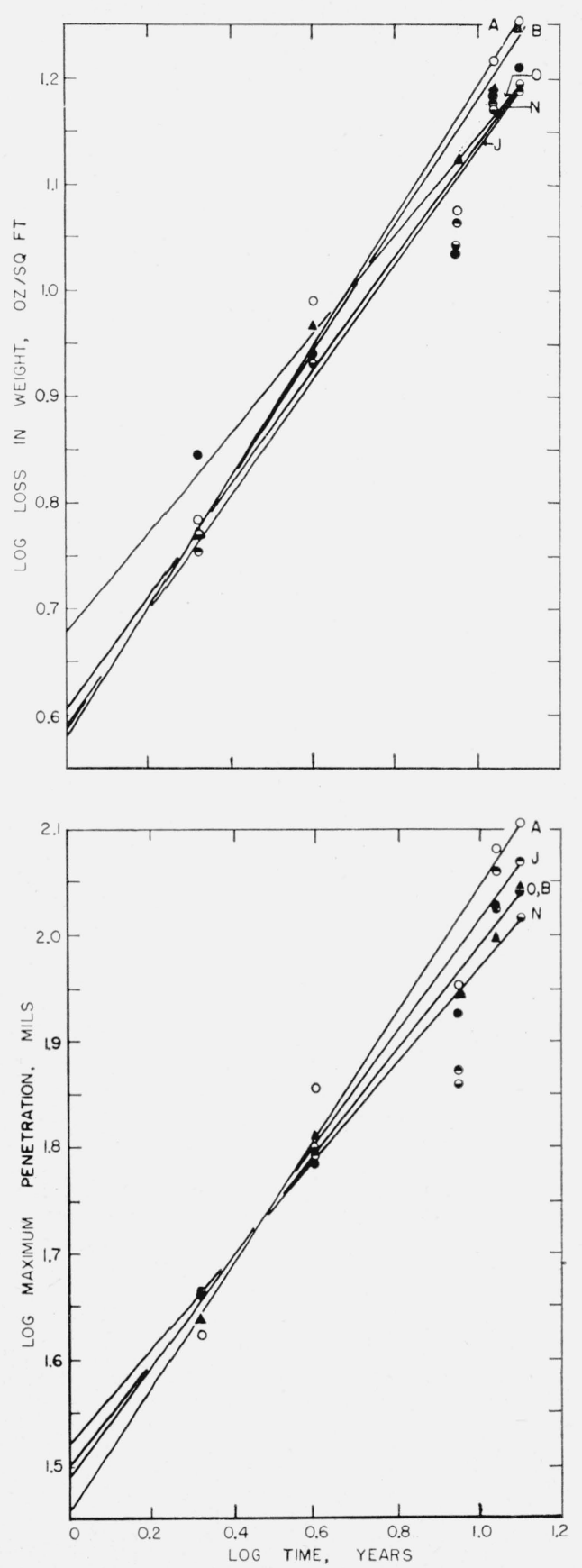

Figure 3. Average loss in weight and maximum penetrationtime curves for copper-molybdenum open-hearth irons and nickel-copper steels in 13 soils.

A, open-hearth steel; $\mathrm{O}$, open-hearth iron, $0.45 \mathrm{Cu}, 0.07 \mathrm{Mo} ; \mathrm{N}$, open-hearth iron, $0.54 \mathrm{Cu}, 0.13 \mathrm{Mo}$; J, steel $0.85 \mathrm{Cu}, 0.52 \mathrm{Ni}$; B, steel, $1.96 \mathrm{Ni}, 1.01 \mathrm{Cu}$.
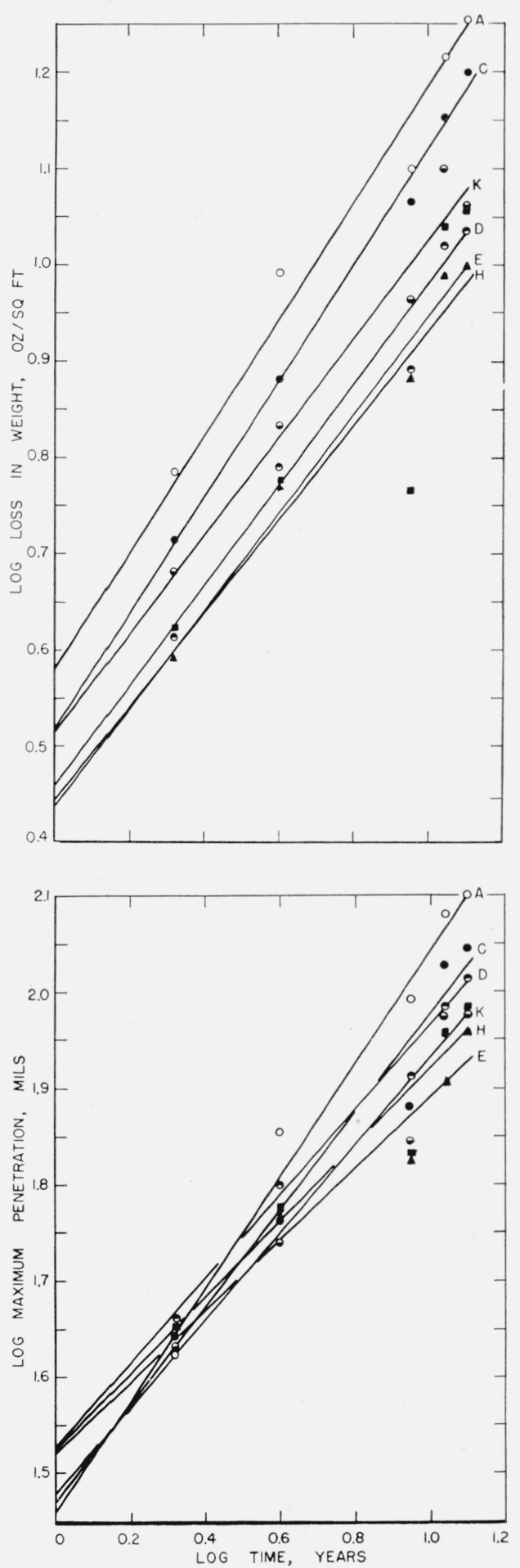

Figure 4. Average loss in weight and maximum penetrationtime curves for chromium and chromium-molybdenum steels in 13 soils.

A, open-hearth steel; C, Cr-Si-Cu-P steel, $1.02 \mathrm{Cr}, 0.42 \mathrm{Cu}$; KK, steel, $2.01 \mathrm{Cr}$, $0.57 \mathrm{Mo}$; D, steel, 5.02 Cr; E, steel, $4.67 \mathrm{Cr}, 0.51 \mathrm{Mo}$; $\mathrm{H}$, steel, $5.76 \mathrm{Cr}, 0.43 \mathrm{Mo}$ 


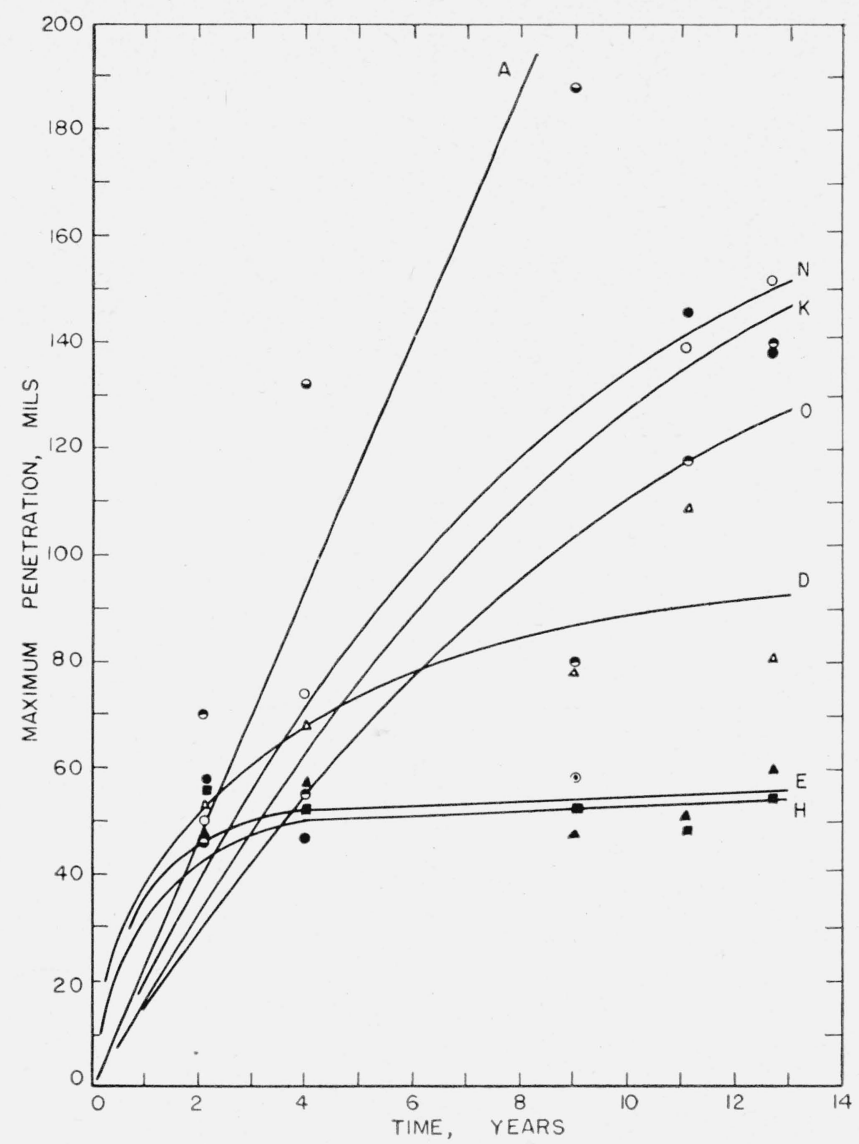

Figure 5. Pit-depth-time curves of copper-molybdenum openhearth irons, chromium and chromium molybdenum steels in cinders.

A, open-hearth steel; $\mathrm{N}$, open-hearth iron, $0.54 \mathrm{Cu}, 0.13 \mathrm{Mo} ; \mathrm{K}, 2$ percent $\mathrm{Cr}$ steel with Mo; D, 5.02 percent $\mathrm{Cr}$-steel; E, 4.67 percent Cr-steel with Mo; H, 5.76 percent Cr-steel with Mo.

Washington, August 22, 1952. 